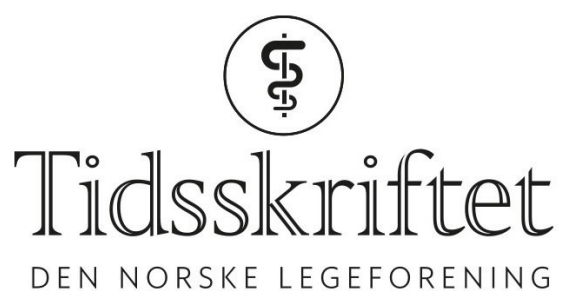

DEN NORSKE LEGEFORENING

\title{
Rutinemessig urindyrkning hos gravide - fordeler og ulemper
}

KOMMENTAR

\section{SIGURD HØYE}

E-post: sigurd.hoye@medisin.uio.no Sigurd Høye er leder av Antibiotikasenteret for primærmedisin. Forfatteren har ikke oppgitt noen interessekonflikter.

Vi vil takke Backe og medarbeidere for et engasjert debattinnlegg mot unødvendig bruk av antibiotika og mot sykeliggjøring av gravide (1). Dette engasjementet deler vi ved Antibiotikasenteret for primærmedisin (ASP).

«Veilederen» Backe og medarbeidere viser til er Nasjonale faglige retningslinjer for antibiotikabruk i primærhelsetjenesten, utgitt av Helsedirektoratet. ASP er en sentral del av redaksjonsgruppen for disse retningslinjene. Helt siden første utgave i 2008 har retningslinjene anbefalt screening for asymptomatisk bakteriuri tidlig i svangerskapet. Nasjonal faglig retningslinje for svangerskapsomsorgen støttet seg til antibiotikaretningslinjene da de ved revisjonen i 2017 gav samme anbefaling.

Ved mange av tilstandene som omfattes av retningslinjene for antibiotikabruk i primærhelsetjenesten, må det gjøres en vekting av fordeler og ulemper ved prøvetaking og antibiotikabehandling. Ett og samme kunnskapsgrunnlag kan resultere i ulike anbefalinger, avhengig av vurdering og vekting. Andre land det er naturlig å sammenligne seg med og som har retningslinjer på dette feltet, anbefaler screening for asymptomatisk bakteriuri i en eller annen form - enten hos alle gravide, som i de britiske NICEretningslinjene og de nye anbefalingene fra Infectious Diseases Society of America, eller hos gravide med høyere sannsynlighet for bakteriuri (hyppige urinveisinfeksjoner før svangerskapet, positiv urinstrimmelundersøkelse, etc), som i Sverige og Danmark.

Cochrane-oversikten på dette feltet har fra 2015 til 2019 endret ordlyd i hovedkonklusjonen, fra at antibiotika er effektivt for å redusere risikoen for pyelonefritt, til at antibiotika kan være effektivt. Det fastholdes i begge versjonene at kunnskapsgrunnlaget er svakt, men vi gjenfinner ikke en spesielt kritisk holdning til generell screening, og heller ikke en avvisning av at asymptomatisk bakteriuri kan føre til lav fødselsvekt.

Nasjonale faglige retningslinjer for antibiotikabruk i primærhelsetjenesten er de eneste retningslinjene som har et system for årlig revisjon. Vi er nå midt i revisjonsarbeidet, og vil ta med oss innspillene videre i dette arbeidet. Retningslinjene sendes med jevne mellomrom på åpen høring, og neste høringsrunde vil foregå første halvår 2021. Det vil da være god anledning til å bli hørt. 
LITTERATUR:

1. Backe B, Jacobsen AF, Magnussen EB et al. Rutinemessig urindyrkning hos gravide - slutt med det. Tidsskr Nor Legeforen 2020;140. doi:10.4045/tidsskr.20.0838. [PubMed][CrossRef]

Publisert: 1. februar 2021. Tidsskr Nor Legeforen. DOI: 10.4045/tidsskr.21.0022

(C) Tidsskrift for Den norske legeforening 2020. Lastet ned fra tidsskriftet.no 